УДК 340.15“09”_“18”:347.6

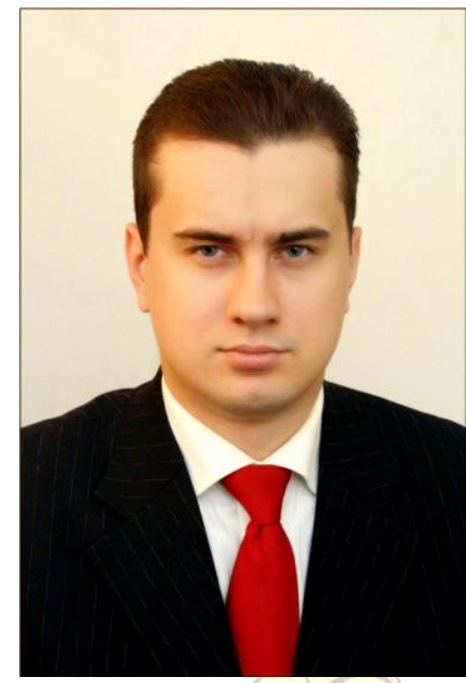

Ю. М. ПОХОДЗІЛО, канд. юрид. наук, доц., доцент кафедри історії держсави і права

Украӥни та зарубізнних краӥн, Національний юридичний університет імені Ярослава Мудрого, Україна, м. Харків e-mail: yurnpo@ukr.net ORCID 0000-0003-4797-2344

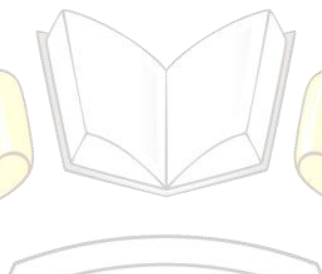


дороги. Сімейні стосунки завжди потребували правового регулювання: звичаї, традиції, писані закони стабілізували їх, спрямовуючи в русло, яке відповідало рівню суспільної потреби та національної свідомості.

На жаль, в Україні інститут сім'ї з кожним роком втрачає своє значення. Сьогодні спостерігається тенденція до так званих «громадянських шлюбів», частими стали розлучення, а молодь взагалі не хоче укладати шлюб. Також слід згадати про вінчання - обряд, який, насамперед, має духовне значення, а не просто укладання договору. Як форма укладання шлюбу воно взагалі втратило своє значення і майже не застосовується. Не можна оминути увагою й одностатеві шлюби, дискусії з приводу яких не припиняються. Існує багато точок зору, різноманітних досліджень і опитувань з цього приводу. У багатьох країнах світу такі шлюби дозволяються, але численні опоненти стверджують, що це суперечить самому визначенню сім'ї та шлюбу. Тому сьогодні виникає необхідність дослідити генезис понять шлюбу і сім'ї.

Аналіз актуальних досліджень. Дослідженню/ питання шлюбносімейного звичаєвого права дохристиянських часів приділяли увагу у своїх працях М. Грушевський, I. Крип'якевич, I. Бєляєв, Н. Бєляєва, М. Владимирський-Буданов, Н. Пушкарьова, В. Сергієвич, В. Шульгін, С. Юшков.

Велике значення мають праці дослідників і збирачів народних звичаїв XIX - початку XX ст., а саме П. Чубинського, I. Оршанського, М. Владимирський-Буданова, M. Грушевського, А. Костяківського, Н. Полонської-Василенко, а також сучасних науковців А. Пономарьова, М. Гришич, О. Івановської та ін.

Питання цивільно-правового регулювання майнових відносин у Київській Русі згідно з нормами Руської Правди було предметом дослідження різних учених. До них можна віднести, зокрема, Б. Грекова П. Музиченка, В. Рубаника, В. Кульчицького, П. Захарченка, В. Сергієвича та ін. 
У XIX ст. питання сімейних відносин, сімейних переділів і спадкування членами однієї сім’ї досліджували О. Бариков, В. Мухін, О. Леонтьєв, М. Качанов, С. Пахман.

Питання шлюбно-сімейних відносин завжди цікавили дослідників, тому що сім'я і родина є основою життя кожної людини. Ця зацікавленість не зменшується з роками, а останнім часом навпаки збільшується, адже люди хочуть дізнатися про звичаї і традиції своїх предків.

Метою статті $\epsilon$ комплексний аналіз становлення шлюбно-сімейних відносин, що виникають 3 факту шлюбу та приналежності до сім'ї на українських землях в процесі їх розвитку упродовж X-XIX ст.

Виклад основного матеріалу. Відповідно до ч. 1 ст. 3 Сімейного кодексу України (далі - Кодекс) сім'я $є$ первинним й основним осередком суспільства. Їі складають особи, які спільно проживають, пов'язані спільним побутом, мають взаємні права та обов'язки [12]. Подружжя вважається сім'єю і тоді, коли дружина та чоловік у зв'язку з навчанням, роботою, лікуванням, необхідністю догляду за батьками, дітьми та 3 інших поважних причин не проживають спільно (ч. 2 ст. 3 Кодексу).

Згідно з ч. 1 ст. 21 Кодексу шлюбом є сімейний союз жінки та чоловіка, зареєстрований В органі державної реєстрації актів цивільного стану. Проживання однією сім'єю жінки та чоловіка без шлюбу не є підставою для виникнення у них прав та обов'язків подружжя. Релігійний обряд шлюбу не $є$ підставою для виникнення у жінки та чоловіка прав та обов'язків подружжя (ч. 2 ст. 21 Кодексу), крім випадків, коли релігійний обряд шлюбу відбувся до створення або відновлення органів державної реєстрації актів цивільного стану (ч. 3 ст. 21 Кодексу) [12].

Питання шлюбно-сімейних відносин у процесі розвитку й становлення нашої держави є найбільш актуальними, оскільки вони вже самі по собі $є$ основою становлення й розвитку суспільства в цілому. Сім'я $є$ основою $\mathrm{i}$ 
складовою суспільства, а суспільство, у свою чергу, формує державу. Сімейне право посідає одне 3 провідних місць серед інших галузей права, оскільки сім’я необхідна кожній людині, вона впливає на її розвиток, ii моральний стан і здоров’я, а також на розвиток суспільства, є одним із факторів підвищення соціальної активності людей. Демократичне суспільство зацікавлене в міцній, духовно і морально здоровій сім’і. Міцна сім’я - міцне суспільство.

Історія розвитку українського сімейного права сягає давніх часів, ще до формування Київської Русі як держави, а тим більше до прийняття християнства. У найдавніші часи нашої історії на українських землях головним фактором регулювання суспільних відносин виступав звичай.

Розглядаючи питання дохристиянських шлюбних звичаїв необхідно звернутися до вивчення літописів. Це майже єдині документи, на основі яких можуть базуватися дослідження/звичаєвого права східних слов'ян стосовно шлюбно-сімейних відносин, і вони вказують на те, що в ті часи шлюб уже виступав як об'єкт правового регулювання [1, с. 29].

Про особливості шлюбних традицій давніх слов’ян можна дізнатись із тексту «Повість минулих літ»: «...А древляни жили подібно до звірів, ...i весіль не бувало в них, а умикали вони дівчат коло води. А радимичі, і вятичі, i сіверяни один обичай мали: .... весіль не було в них, а ігрища межи селами. I сходились вони на ігрища, на пляси і на всякі бісівські пісні, i тут умикали жінок собі, - з якою ото хто умовився. Мали ж вони по дві і по три жони» [13, c. 30]. Вивчаючи рядки літопису слід враховувати ту обставину, що літописець висловлює своє ставлення до язичницьких шлюбних звичаїв, спираючись на норми християнської моралі. Тому форми укладення шлюбу, які існували в язичницькі часи, жодним чином не могли бути сприйняті як законні в контексті вже християнського бачення [1, с. 29].

Особисті майнові й не майнові права та обов'язки подружжя залежали від форм і умов укладання шлюбу.

(С) Походзіло Ю. М., Силенок К. П., 2015 
Найдавнішою формою укладання шлюбу на українських землях в IV VII століттях було «умикання», тобто викрадення хлопцем дівчини, яку він хотів мати за дружину. Шлюби укладались під час великих свят, де наречена віддавалася нареченому в присутності великої кількості народу. Прилюдність тягнула за собою певний договірний характер шлюбу. Якщо наречений оголошував свою наречену, то вже не мав можливості від неї відмовитися [1, c. 30].

Розглядаючи шлюбні традиції викрадення нареченої слід говорити про домовленість родів, своєрідне сватання, що базувалось на виплаті віна для припинення або попередження міжродової ворожнечі, що виникала на тлі викрадення нареченої. Із плином часу віно перетворилося на прямий продаж нареченої нареченому за попередньої домовленості між родичами обох сторін.

Таким чином, можна дійти висновку, що насильницьке викрадення із часом трансформувалось у звичай викупу нареченої. Тут вже можна говорити про другу форму укладання шлюбу - купівля нареченої. Сам шлюб при купівлі являв собою лише перехід влади на наречену, за домовлену ціну від батьків до иї майбутнього чоловіка [1, с. 30].

Поляни, у порівнянні 3 іншими племенами, зображуються як такі, що мали в ті часи більш розвинені шлюбні традиції. Шлюб у полян набув більш зрілої форми - «приведення». Треба зазначити, що обряд приведення, хоч і був символічним, але мав вагоме юридичне значення - він перетворював фактичне співжиття чоловіка і жінки на законний шлюбний союз.

Можна виділити наступні особливості «приведення»: простежується існування як віна, так і приданого; шлюб набував більш вагомого значення, порівняно з іншими язичницькими формами шлюбу; як найбільш наближена форма шлюбу до християнського світогляду, деякі їі елементи залишилися в українській шлюбній обрядовості ще на багато століть [1, с. 32].

У дохристиянські часи в основі шлюбу часто були політичні вигоди (С) Походзіло Ю. М., Силенок К. П., 2015 
правлячої верхівки. Поширеним також було багатоженство (полігамія), пов’язане з уявленням про жінку як про власність, яка може бути продана батьками і куплена чоловіком.

Отже, можна дійти висновку, що шлюб регулювався звичаєвим правом та язичницькими обрядами й розглядався як звичайна майнова угода, що вільно укладалася й розривалася. Відносини між чоловіком i дружиною будувалися на залежності жінки від чоловіка, як особистій, так і майновій. Навіть придане, яке давалося за нареченою иї батьком, не могло змінити це залежне становище дружини від чоловіка $\mathrm{i}$ дати їй право на рівність $з$ ним у сімейних справах.

Також слід зазначити, що при викраденні нареченої вона ставала власністю чоловіка, i/ тоді виникали права більше речового характеру, а не особистого. Дружина ставала річчю і відношення до неї було як до речі. При купівлі нареченої та при «приведенні» дещо обмежувалась влада чоловіка i залежність дружини дещо зменшувалась.

Після прийняття християнства сімейне право розвивалося відповідно до візантійського канонічного права. Адже Хрещення Русі сприяло прийняттю нормативних актів, джерелами яких були візантійські церковні акти. Разом 3 новою вірою по-новому почали формуватися поняття про шлюб і сім'ю. Християнство надало святості шлюбу, визнало шлюб не лише природнім союзом чоловіка та жінки, в який вони добровільно вступають, обіцяючи бути вірними один одному, але й Таїнством, духовним єднанням. Установлювалась одношлюбність (моногамія). Християнське право вступало в конфлікт із звичаями дохристиянської доби i визнавало шлюби освячені церквою, обрядом вінчання. Церква прагнула відмінити весільні обряди, що існували раніше, щоб люди брали шлюб лише за церковним обрядом i забули дохристиянські звичаї. Це було пов’язано з бажанням об’єднати населення на основі однієї віри під владою одного князя [2, с. 46]. 
Поширеним законодавчим документом у питаннях шлюбу були Кормчі книги, збірники, які містили греко-римські закони, постанови соборів, думки i погляди відомих діячів церкви. У Кормчих є два визначення шлюбу, які не суперечать одне одному: «Брак есть мужеви и жене сочетание и событие во всей жизни, божемтвенная и человеческая правды общения» та «Супружество или законный брак тайна от Христа Бога уставлен есть, во умноження рода человеческого и в воспитании чад к славе Божей в неразрешимый союз любви и дружества и во взаимную помощ и в еже огребатися греха любодеяния» [7, c. 5-6].

Отже, шлюб являв собою союз двох осіб для народження дітей та уникнення гріховного життя, він укладався один раз і на все життя. Суть християнського шлюбу суперечила розумінню шлюбу в язичництві, який допускав свободу розлучень і незалежне існування подружжя. Крім того, складності виникали через те, що християнський шлюб повинен був укладатися з дотриманням багатьох вимог і формальностей, які були створені візантійським законодавством і використовувалися на Русі [7, с. 5-6].

Загалом використовувалась давня форма укладання шлюбу - весілля шлюбна гостина, яка супроводжувалась старовинними обрядами. Саме воно вважалось днем укладання шлюбу і давало право на спільне життя. Весілля зазвичай грали восени від Покрови до Пилипівського посту або взимку від Хрещення до Масниці. Передвесільні дні починалися з відправлення молодого i молодої на «запросини». Запрошували зазвичай усіх родичів і сусідів. Обов’язковою дією було прощання нареченого і нареченої зі своєю свободою, акт їх відокремлення від не сімейної групи молоді. Якщо весілля чомусь відкладалось, звичай не дозволяв жити разом.

Важливою традицією для укладання майбутнього шлюбу було отримання батьківського благословення. У більшості випадків батьки прислухались до бажання дітей, але попри свободу вибору наречених, 
прийнято було одружуватись тільки з дозволу батьків. Без батьківської згоди шлюб не міг стати дійсним, а якщо й бували такі шлюби, то це вважалось аномалією. Тому остаточне рішення завжди було за батьками [3, с. 47].

Саме домовленість між батьками молодих про намір одружити дітей була тією базою, на основі якої складалися всі подальші відносини. Така домовленість ставала приводом для сватання, коли батьки або родичі молодого засилали сватів до родини молодої з пропозицією про шлюб. Як традиційний звичай, після сватання відбувалися оглядини, коли батьки нареченої приходили до помешкання, де житиме майбутня сім'я, й оцінювали майновий стан нареченого. Якщо родину молодої щось не влаштовувало, вона могла розірвати попередню домовленість про майбутній шлюб [2, с. 47].

Потім розпочинався наступний етап - заручини. Заручини - це дуже важливий в юридичному значенні акт. Під час заручин домовлялися про розподіл витрат на підготовку весілля, весільні подарунки, придане нареченої та частку сина у разі відділення молодої сім’ї від батька тощо.

Після заручин розпочиналася активна підготовка до весілля, i якщо угода про майбутній шлюб на цьому етапі з якихось причин розривалася, то це вже тягнуло за собою певні санкції для сторони, яка відмовилася. Зокрема, на неї покладався обов'язок відшкодувати витрати на пригощання під час сватання і заручин, подарунки та приготування до весілля [3, с. 47].

Під час укладання шлюбного договору вже остаточно встановлювався посаг нареченої та віно, що вносив наречений. Посаг - майно, яке видавали батьки дочці. Віно - майно, яке приносив у шлюб чоловік. Посаг складали рухомі речі, які у свою чергу поділялись на дві групи. Першу групу складали гроші, золото, срібло, перли, дорогоцінне каміння; другу - жіночий одяг, білизна, коні та інші рухомі речі. Віно - третина нерухомого майна, яким забезпечувався посаг дружини. Для встановлення рівності посагу і віна впровадилась оцінка посагу за участі відповідних знавців. П'ять предметів 
першої групи оцінювались вдвічі більше від їхньої реальної вартості. Додаткова вартість називалась привінком i була подарункам нареченій за вінець дівочий - символ цнотливості нареченої. Посаг переходив у володіння родини, але віно залишалося назавжди власністю дружини.

У Київській Русі взаємини між чоловіком і дружиною здійснювалися на принципах рівноправності, духовності, гуманізму і справедливості. Правове становище жінки в сім’ї було, як для того часу, на високому рівні, iï права охороняла держава. Матір за Руським правом мала набагато вищий правовий статус ніж за римським і старогрецьким правом, за яким дочка, дружина, матір завжди потребували опікуна та визнавалися все життя не «правосильними». У Київській Русі жінка була наділена цивільною дієздатністю і за життя чоловіка зберігала своє окреме майно, яке й після його смерті не входило до спільної спадщини, а вона ставала повноправним головою сім’і. Жінка самостійно вела господарство, розпоряджалася власністю і від неї залежало відділення синів для ведення власного господарства. Жінка могла укладати різноманітні договори купівлі-продажу, позики, застави, дарування, успадкування [5, с. 30].

На жаль, наші літописи свідчать лише про представниць вищих верств населення, які займали визначне становище у житті суспільства, як, наприклад, княгиня Ольга, і зовсім не згадують про жінок, які не належали до панівних класів. Тому з’ясувати, на яких правових засадах будувалися майнові відносини між чоловіком та дружиною у сім'ях селян та міщан, важко. У народі міцно жила ідея приналежності дружини чоловікові, тому представниці нижчих соціальних груп, ймовірно, не мали права розпоряджатися своєю власністю [14, с. 210].

На формування сімейного права Київської Русі вплинуло візантійське канонічне право, але в церковній практиці Київської Русі відбулося відхилення від візантійського законодавства. Так, згідно 3 візантійським правом розлучення можна було просити у таких випадках: порушення (С) Походзіло Ю. М., Силенок К. П., 2015 
подружньої вірності, при нездатності чоловіка до інтимних стосунків після трьох років співжиття, коли чоловік або жінка намагалися позбавити життя один одного. Згодом до цих причин було додано інші, зокрема, коли чоловік чи жінка постриглись в ченці, коли невідомо, де чоловік перебував протягом п’яти років, коли жінка без дозволу чоловіка ночує не вдома, а у своїх родичів, тощо [5, с. 30].

У той час, як Статут князя Ярослава перелічував не всі приводи до розлучення, зазначені у візантійському праві, у ньому встановлювались i приводи до розлучення, що були невідомі візантійському праву. Це пов’язано 3 тим, що процес формування норм вітчизняного шлюбного права спирався не лише на візантійське шлюбне право, а й на трансформовані давні шлюбносімейні обряди, звичаї.

Нерівноправне становище жінки 3 чоловіком було при вирішенні питання про розлучення, яке регулювалося Статутом Ярослава. Характерно, що обов'язкове розлучення наставало тільки в разі провини дружини [15, с. 44]. Подружня невірність чоловіка не надавала підстав для розлучення дружинам. Пам'ятки канонічного права походження приписували жінкам терпляче чекати «отшедшю мужу» й зберігати подружню вірність. Позитивним аспектом при регулювання питанні стосовно розлучення було те, що дружина отримувала матеріальну компенсацію від чоловіка. Розміри цих відрахувань залежали від соціального статусу подружжя [16, с. 23].

Так, у ст. 53 Статуту князя Ярослава про церковні суди у Просторовій редакції вказано шість провин дружини, які були підставою для розлучення: якщо дружина дізналась і не повідомила чоловіка про майбутній напад на монарха; порушення подружньої вірності; коли дружина намагалась позбавити життя чоловіка або не повідомила про майбутній напад; коли жінка без дозволу чоловіка не ночує вдома, що може загрожувати іiі честі; відвідування дружиною без супроводу чоловіка вдень чи вночі ігрищ; 
крадіжка у чоловіка або співучасть у крадіжці будь-якого майна, зокрема майна церкви [4, с. 207].

Перші п’ять «провин» вказані в пам’ятках візантійського права - в 117 новелі Юстиніана. Проте статті Статуту князя Ярослава, посилаючись на текст візантійських пам’яток, викладають відповідні норми із значними змінами, скороченнями i доповненнями, не перекладаючи їх дослівно. Остання ж «вина» взагалі відсутня у візантійських джерелах [4, с. 207].

Згідно з церковним статутом, дружина мала право вимагати розлучення у випадку: коли чоловік торгував честю своєї жінки; коли чоловік задумував недобре проти держави; коли чоловік звинувачував дружину в статевих стосунках з іншими чоловіками, не маючи доказів; коли чоловік приводив у дім коханку або є докази про статеві стосунки чоловіка 3 чужою жінкою. Церква встановила досить серйозні покарання для чоловіка за самовільні розлучення рублем або гривнею, причому сума змінювалась в залежності від соціального статусу подружжя. Ці питання належали суто до їі компетенції [5, c. 30].

3 поступовим розпадом патріархальних відносин почала розвиватися свобода заповітних розпоряджень. Деякі члени сім ’i починають претендувати на більшу частину спадку (сини), інші ж члени сім’і повністю відсторонюються від спадкування (дочки та дружини). Так виникло спадкування за заповітом. Обмежувалося свавілля чоловіка при складанні заповіту. Він мав право заповідати лише тим, хто був визнаний спадкоємцем у законі. Лише на користь церкви можна було заповідати за наявності інших спадкоємців за законом. Батько мав право розподілити своє майно серед синів, а бояри - і серед дочок також.

Материзною жінка могла розпоряджатися більш вільно, ніж чоловік отчиною. Мати-вдова мала право заповідати своє майно всім дітям, або тому 3 них, хто буде iii утримувати. Вона могла обійти сина, заповівши майно дочці. 
Коли ж мати не встигла зробити заповіт, то майно переходило до того $з$ дітей, 3 ким вона проживала [5, с. 32].

Також треба зазначити, що в Руській Правді вперше зроблено спробу вирізнити батьківське і материнське майно, а також права спадкоємців батьківського і материнського спадкового майна. Пізніше питання «дідизни», «батьківщини», «материзни» знайшли своє логічне продовження i обгрунтування у статутах Великого князівства Литовського, а різниця щодо успадкування батьківського i материнського майна стала характерною особливістю литовсько-руського права [6, с. 11].

3 огляду на викладене вище можна зробити висновок, що в язичницькі часи, коли жінка та іiі майно належали чоловікові, годі було говорити про можливість останньої вільно ім розпоряджатися. 3 прийняттям християнства поступово змінюється погляд, як на жінку, так і на ії права в сім’ї. Жінка за часів Київської русі мала власне майно, яке складалося 3 приданого, віна $\mathrm{i}$ того, що було вироблено іï руками. Але можливість розпорядження цим майном залежала від соціального статусу жінки [14, с 213].

Шлюбно-сімейне право Київської Русі було своєрідним і не повторним, адже формувалося на основі візантійського законодавства, язичницьких обрядах, різноманітних народних звичаях та княжого законодавства.

Існує й інша форма - вінчання - укладання шлюбу в церкві за участю священика. Церковне вінчання проводили іноді в один день 3 весіллям, іноді заздалегідь, але воно не було головною дією шлюбу. Хоча за деякими даними церковне вінчання стало поширюватися ще за часів княжої доби, однак спочатку лише вищі верстви населення одружувалися церковним шлюбом. Вінчання впроваджувалося поступово, лише з середини XVIII ст. (у деяких західних областях - з початку XVI ст.) стало складовою укладання шлюбу для широких верств населення. Тільки в 1774 р. Священний Синод видав указ, загрожуючи анафемою тим, хто жив без вінця. Однак упродовж багатьох років 
значення шлюбного договору і весілля не зменшувалося.

Шлюб укладався за взаємної згоди осіб, які одружувалися. Закон навіть забороняв батькам чи опікунам примушувати до шлюбу. Разом із тим заборонялося брати шлюб без згоди батьків чи опікунів. Існували окремі положення законодавства стосовно Полтавської та Чернігівської губерній: якщо мати чи батько забороняли шлюб повнолітньої дочки, маючи опікунство над їі власністю, вона могла оголосити в суді про цю причину і взяти шлюб 3 дозволу суду [8, с. 65].

При укладенні шлюбу робився запис у метричній книзі. Ці книги виникли після церковного собору 1666-1667 pр. До цього часу дату вінчання записували у «вінечну пам'ять». У метричних книгах потрібно було записувати імена одружених, хрещених i померлих прихожан. Однак до початку XVII століття метричні книги майже не використовувалися. У 1721 р. Петро I видав указ про ведення метричних книг в усіх церквах $[7$, с. 85].

Детально регламентувалися шлюби православних 3 особами інших християнських конфесій. Вони дозволялися державою, але наречені - не православні повинні були давати підписку, що не перешкоджатимуть православній вірі свого обранця, не схилятимуть до переходу у свою віру, а народжені у шлюбі діти будуть хрещені в православ'я. Якщо шлюб між православним i католиком укладався римо-католицьким священиком, він вважався не дійсним доти, доки не відбудеться вінчання у православній церкві $[8$, c. 65].

До 1840 р. шлюби православних 3 неправославними могли укладатися лише з дозволу архієрея, але згодом шлюби російських підданих православної та римо-католицької віри 3 не християнами були заборонені й ця заборона існувала і на початку XX ст. [8, с. 65].

Дуже сильною була централізація духовної влади в сімейному праві у відношенні вищого духовного керівництва до нижчих органів влади - 
священників. Був час, коли жоден шлюб не міг бути укладеним без дозволу єпархіальної влади, в якої молодята повинні були отримати «вінечну пам'ять», тобто дозвіл вступати до шлюбу. Вінечна пам’ять була змінена лише в 1765 р., але ще довгий час священики не могли вільно, без дозволу єпархіальної влади, виконувати свої обов'язки, які стосувались сімейного права. Наприклад, якщо вінчання в церкві не є можливим, то його можна здійснити в приватному будинку, але не інакше, як з дозволу архієрея. Звісно, у глухих, віддалених місцинах, де зазвичай вінчання відбувалось у приватних будинках, дозвіл архієрея було дуже складно отримати [9, с. 256-257].

Для спрощення і полегшення процесу укладення шлюбу 1897 р. був виданий Збірник церковних і цивільних законів про розлучення і судочинство у шлюбних справах, де було сказано, що особи православного віросповідання можуть брати шлюб як між собою, так і/з іноземцями православного й усіх інших християнських віросповідань, не просячи особливого дозволу від влади, але $з$ дотриманням всіх шлюбних вимог $[11$, с. 5].

У XVḦ ст. шлюб припинявся лише у разі смерті одного 3 подружжя, тоді дозволявся вступ у новий шлюб. Щодо можливості розірвання шлюбу, то умови були настільки обмежені, що це була майже заборона. Шлюб міг бути розірваний тільки духовним судом на прохання одного 3 подружжя у випадках: доказу перелюбства або нездатності до шлюбного співжиття; один 3 подружжя засуджений до покарання з позбавленням всіх прав, або засланий до Сибіру з позбавленням прав і майна; безвісна відсутність одного 3 подружжя [8, с. 66].

Слід підкреслити, що дуже мала вірогідність розлучень у ті роки була обумовлена не тільки жорстким законодавством, а й різким осудом церкви, громади, всього оточення. Вважалося, що розлучення є відхиленням від соціально прийнятих норм поведінки, тому розірвати шлюб могли дозволити собі лише представники вищих соціальних верств населення, які були (С Походзіло Ю. М., Силенок К. П., 2015 
економічно і соціально захищені.

Держава і церква підтримували патріархальну модель взаємовідносин між подружжям. Відповідно до законодавства, подружжя зобов'язано було жити разом, і при зміні місця проживання чоловіка з якоїсь причини, дружина повинна була слідувати за ним. Чоловік зобов'язаний любити свою дружину, жити з нею у згоді, прощати іiі недоліки, допомагати, забезпечувати дружині прожиток i утримання по можливості. Обов'язок дружини - коритися чоловікові як голові сім’і, жити 3 ним у любові, шануванні та виконувати обов’язки хазяйки дому. Разом із тим, навіть після заміжжя жінка зберігала певну економічну самостійність: придане дружини, а також власність (маєток), придбана на їі ім’я під час шлюбу, вважали іï окремою власністю. Хоча щодо мешканців Чернігівської і Полтавської губерній ця норма закону мала певні корективи: придане дружини хоча i вважалося іiі власністю, знаходилось у спільному володінні та користуванні подружжя [8, с. 66].

Проте завжди існували деякі суперечності: на практиці дружина все-ж дуже залежала від чоловіка. Наприклад, у середині XVIII ст. Аксінья Головніна подала прохання до Урядового Сенату, в якому пояснювала, що має власне рухоме і не рухоме майно, яке хоче продати, проте юстиц-колегія не виписує «продажних» на іiі ім'я, а вимагає дозвіл від чоловіка. Розглянувши прохання, Сенат усе-ж дозволив Аксіньі розпоряджатись майном без дозволу чоловіка, посилаючись на закон 1753 р. Такі випадки не були поодинокі [10, с. 1].

Законодавство встановлювало повну самостійність дружини в іiі майнових відносинах, але разом із тим була ціла низка обмежень особистих i майнових прав заміжніх жінок. Відповідно до ст. 2 Уставу про Векселя (т. XI, ч. 2, вид. 1903 р.) заміжня жінка без дозволу чоловіка не могла видавати й отримувати векселя на своє ім'я. Згідно із Законами Цивільними (т. Х, ч. 1, вид. 1900 р., ст. 2202), Устав про Промисловість (т. ХІ, ч. 2, вид. 1893 р., ст. 90) і Положення про найм на сільські роботи (т. ХII, ч. 2, вид 1906 р., 
ст. 10-11), будь-який особистий найм заміжніх жінок залежав виключно від дозволу чоловіка. Відповідно до ст. 12 Уставу про Паспорти (т. XIV, вид. 1903 р.) дружина не могла отримати власне житло без згоди чоловіка, також для вступу заміжньої жінки в деякі навчальні заклади, на державну та громадську службу вимагався дозвіл чоловіка. Для усунення подібних суперечностей 12 березня 1914 р. був виданий Закон про деякі зміни i доповнення до чинного законодавства про особисті та майнові права заміжніх жінок про відносини подружжя між собою та з дітьми [10, с. 2].

Висновки. Дослідивши різні форми укладання шлюбу в язичницьку епоху, можна стверджувати, що відголоски давніх звичаїв можна спостерігати і сьогодні у шлюбній обрядовості.

Прийняття християнства створило сприятливі умови для стрімкого розвитку суспільних, економічних, політичних та духовних відносин, підготувавши грунт для систематизації правової системи як взагалі, так і у сфері шлюбно-сімейних відносин. Християнство, зокрема православна церква, справило великий вплив на формування нових морально-етичних норм життя, які певною мірою знайшли своє відбиття в новій правовій системі. Подальша еволюція права відбувалась у бік гуманізації. Отже, християнська церква стала стабілізуючим фактором суспільно-політичного ладу і правового розвитку як Київської Русі, так і сучасної України.

Положення звичаєвого права XVII - XVIII ст. знайшли відображення у законах Російської імперії стосовно шлюбу, умов його укладання i припинення, сімейних прав і обов'язків тощо. Ці закони, окремі положення яких почали діяти з кінця XVII-XVIII ст., у XIX ст. вже повністю регулювали шлюбно-сімейні стосунки населення країни, в тому числі України як складової Російської імперії, і діяли до жовтневого перевороту 1917 р. Проте вони були не однозначними й часто суперечили один одному. 3 одного боку, вони надавали широку свободу і самостійність жінкам, а $з$ іншого - повністю 
заперечували їх права. Повне єднання держави і церкви, яке було одним iз важливих принципів організації суспільства у той період, стало серцевиною шлюбного законодавства: у законах вказані не тільки особливості укладання шлюбу окремих верств населення, а й діяли окремі положення законів стосовно шлюбу осіб різних християнських конфесій і шлюбу не християн. Держава визначала законним лише церковний шлюб, головним доказом шлюбного союзу був запис у приходській (метричній) книзі. Щодо прав i обов’язків подружжя, то вони повністю контролювались церквою, державою і відповідали тогочасним соціальним вимогам, хоча й не повністю задовольняли бажання членів сім’i $[8$, с. 64-65].

\section{Список літератури:}

1. Озель В. Форми укладання шлюбу в Україні у до християнські часи / В. Озель // Юрид. Україна - 2010. -№ 10. - С. 29-30.

2. Бирлюк O. М. Формування шлюбу в Київській Русі: норми звичаєвого та церковного права / О. М. Бирлюк // Часопис Київ. ун-ту права - 2010. - № 4. - С. $44-48$.

3. Іванов B. Укладання шлюбу за українським звичаєвим правом / В. Іванов, В. Озель // Персонал. - 2007. - № 5. - С. 4449.

4. Российское законодательство X - XX векав : в девяти томах. - T. I: Законодательство Древней Руси. - М. : Юрид. лит., 1984. - 432 с.

5. Бойко І. Й. Правове регулювання цивільних відносин в Україні (IX - XX) : навч. посіб. / І. Й. Бойко ; Львів. нац. ун-т. ім. Франка - К. : Атіка, 2013. -347 с.

6. Полін O. Співвідношення сімейної власності і спадкування у Київській Русі / О. Полін // Юридична Україна. - 2010. - № 8. - С. 11-15.

7. Цатурова M. К. Русское семейное право XVI-XVIII вв. / М. К. Цатурова. - М. : Юрид. лит., 1991. -108 с.

8. Слюсар Л. І. Еволюція шлюбу в Україні: XVII - початок XX сторіччя / Л. І. Слюсар // Демографія та соц. економіка. - 2011. - № 2.-С. 62-72.

9. Орианский И. Г. Исследование по русскому праву: обачному и брачному / И. Г. Оршанский. - Спб. : Типогр. Ландау, 1879. -455 с.

10. Закон 12 марта 1914 года о некоторих изменениях и дополнениях действ. узаконений о личн. и имущств правах замужних женщин об отношениях супругов между собой и к детям // Собр. Узак. 1914 г. - Ст. 1902 / сост. П. С. Ципкин. - Спб. : Законоведение, 1914. - 114 с.

11. Григоровский C. Сборник церковных и гражданских законов о разводе и судопроизводстве по делам брачним. С доп. и розьясн. по цирк. сепаратн. указами Святейш. Синода и с прилож. табл. графыч. изображ. степеней родства и свойства / С. Григоровский. - Изд. 3-е. - Спб. : Скоропечатная Я. И. Либермана, 1897. - 232 с.

12. Сімейний кодекс України : Закон України від 10.01.2002 р. № 2947-III (з наступними змінами та доп.) // Відом. Верхов. Ради України. - 2002. - № 21-22. - Ст. 135.

13. Літопис руський / пер. $з$ давньорус. Л. Є. Махновця ; відп. ред. О. В. Мишанич. - К. : Дніпро, 1989. - XVI + 591 c. 
14. Омельянчук C. B. Майнові відносини подружжя за давньоруським правом / С. В. Омельянчук // Вісник Нац. ун-ту внутр. справ. - Вип. 29. - Х. : Нац. ун-т внутр. справ. ; відп. ред. О. М. Бандурка, 2005. - С. 208-213.

15. Статут князя Ярослава про церковні суди: (Просторова редакція) // Хрестоматія з історії держави і права України : навч. посіб. для юрид. вищ. навч. закладів і ф-тів : у 2 т. / В. Д. Гончаренко, А. Й. Рогожин, О. Д. Святоцький ; за ред. В. Д. Гончаренкаю. - К., 1997. - Т. 1: 3 найдавніших часів до початку XX ст. -464 с.

16. Анімук H. B. Тенденції розвитку інституту конституційно-правового статусу жінок в Україні : дис. ... канд. юрид. наук : 12.00 .13 / Н. В. Аніщук ; Одеська нац. юрид. академія. - Одеса, 2001. $-225 \mathrm{c}$.

Походзило Ю. Н., Силенок К. П. Эволюция правового регулирования брачносемейных отношений на украинских землях в X-XIX столетиях.

Проанализировань вопросы становления брачно-семейных отношений, которые возникают по факту брака и принадлељности к семье, на украинских землях в процессе их развития в $X-X I X$ веках.

Ключевые слова: брачно-семейные отношения, брак, личные имущественные и неимущественные права супругов.

Pokhodzilo Y. N., Silenok K. P. Evolution of the legal regulation of marriage and family relations in Ukrainian lands during $\mathrm{X}$ - XIX centuries.

The article is a comprehensive analysis of the formation of marriage and family relations arising from the fact of belonging to a marriage and family in the Ukrainian lands in their development during $X$ XIX centuries.

Key words: marriage and family relations, marriage, property and non-property personal rights of spouses.

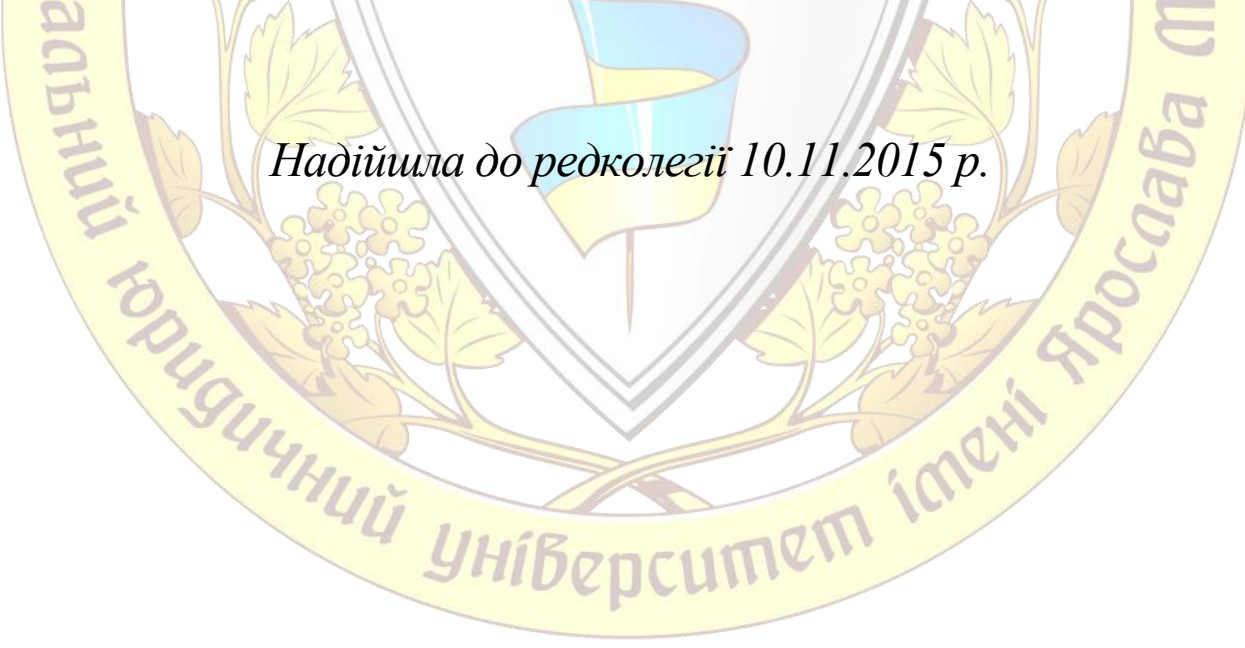




\section{Розширена анотація}

статті Походзіла Ю. М., Силенок К. П. Еволюція правового регулювання шлюбно-сімейних відносин на українських землях у X - XIX століттях

Pokhodzilo Y. N., candidate of legal sciences, assistant professor of the History of State and Law for Ukraine and foreign countries Department, Yaroslav Mudryi National Law University, Kharkiv.

Silenok K. $\boldsymbol{P}$., 2nd year student of group 3, Personnel Training Institute for the Ministry of Internal Affairs of Ukraine, Yaroslav Mudryi National Law University, Kharkiv.

Extended abstract of the article:

Evolution of the legal regulation of marriage and family relations in Ukrainian lands during X - XIX centuries

Statement of problem. In Ukraine nowadays every year the family institution loses its meaning. There is a growing trend towards so-called "civil marriage", frequent divorce, and young people do not want to marry. You should also remember the wedding, ceremony, which is primarily a spiritual meaning, not just a contract. As a form of marriage in general it has lost its value and almost never used. We can not ignore and gay marriage, the debate over which unabated. There are many points of view, various studies and surveys on this. In many countries, such marriages are allowed, but multiple opponents argue that it is contrary to the very definition of family and marriage. So today there is a need to explore the genesis concepts of marriage and family.

Recent research and publication analysis. The question of marriage and family relations was always interested researchers because the family and the family is the foundation of every human life. Recent research and public study on matrimonial customary law pre-Christian times in his writings pay attention Hrushevsky, Ivan Krypiakevych, I. Belyaev, M. ascend-Budanov, V. Serhiyevych, Shulgin, S. Yushkov, N. Pushkarev, N. Belyaev. The question of civil-legal regulation of property relations in 
Kievan Rus according to the norms of $\mathrm{n}$ Pravda was the subject of study of various scientists. These include, in particular, B. Grekov, P.Muzychenko, V. Rubanyka, W. Kulczycki, P. Zakharchenko, V. Serhiyevycha and others. In the nineteenth century the question of family relations, family and inheritance redistribution members of one family studied Pahman S., M. Kachanov, Barykov A., Mukhin, Alexander Leontiev.

Paper objective. The article is a comprehensive analysis of the formation of marriage and family relations arising from the fact of belonging to a marriage and family in the Ukrainian lands in their development during X - XIX centuries.

Paper main body. Analyzed the issue of marriage and family relations in the process of formation and development in Ukraine. History of the Ukrainian family law reaches ancient times, even before the formation of Kievan Rus as a state, let alone the adoption of Christianity. In ancient times in our history the Ukrainian lands major factor regulating social relations advocated custom. Personal property and non-property rights of spouses dependent on the shape and conditions of marriage. Matrimonial law Kievan Rus was a kind and unique because formed based on Byzantine law, pagan rituals, various folk customs and princely legislation. To simplify and facilitate the marriage in 1897 was issued a collection of religious and civil laws on divorce and judicial proceedings in matrimonial matters, where it was said that people of Orthodox religion can marry among themselves and with foreigners Orthodox and all other Christian denominations not asking for special permission from the authorities, but with all the marriage requirements.

Conclusions of research. Examining the different forms of marriage in the Pagan era, one could argue that the echoes of ancient customs can be seen today in the marriage rites.

The adoption of Christianity created favorable conditions for the rapid development of social, economic, political and spiritual relations, preparing the ground for organizing the legal system, both in general and in the field of marriage and family relations. Christianity, including Orthodox Church, had a great influence on the formation of new ethical norms of life which, to some extent found their reflection in the new legal system. Further evolution took place right in the direction of humanization. Thus, the Christian church has become a stabilizing factor in the socio-political system and legal development as Kievan Rus and 
modern Ukraine.

The provisions of customary law XVII-XVIII reflected in the laws of the Russian Empire concerning marriage, conditions for its conclusion and termination, family rights and responsibilities and so on. These laws, some provisions of which began to operate from late XVII-XVIII century. In the nineteenth century. already fully regulate marriage and family relationships population, including Ukraine as part of the Russian Empire, and acted to the October revolution in 1917 however they were not straightforward and often contradicted each other. On the one hand provide extensive freedom and independence of women, on the other - completely denied their rights. Full union of church and state, which was one of the important principles of society at the time, was at the heart of marriage laws: the laws given not only features the marriage of some segments of the population, but were certain provisions of the laws concerning marriage of people of different Christian denominations and marriage do not Christians. The state determined the only legitimate church marriage, the main proof of marriage was a record in the parish (metric) book. As for the rights and responsibilities of spouses, they are completely controlled by the church, the state and meet the requirements of the then social, though not entirely satisfy the desire of family members.

Key words: marriage and family relations, marriage, property and non-property personal rights of spouses. 